\title{
Diabetes: discovery of insulin, genetic, epigenetic and viral infection mediated regulation
}

\author{
Sumit Ghosh ${ }^{1}$. Sushweta Mahalanobish ${ }^{1} \cdot$ Parames C. Sil $^{1}$
}

Received: 16 July 2021 / Accepted: 23 September 2021 / Published online: 5 October 2021

(c) Archana Sharma Foundation of Calcutta 2021

\begin{abstract}
Diabetes mellitus, commonly referred to as diabetes, is a combination of many metabolic diseases. Insulin deficiency in our body is the main cause of diabetes. Insulin is one of the most well studied proteins, yet the genesis of its discovery was not getting much attention so far. Nevertheless, the history of the discovery of insulin is an exemplary of solving observational and scientific riddles, drudgery, patience and even professional turmoil. It is an inspiration for all medical personnel and scientists who are practising in the field of molecular medicine. Additionally, the genetic and epigenetic regulation of different types of diabetes needs to be addressed because of the widespread nature of the disease. Diabetes not only involves genetic predisposition but environmental factors, lifestyle etc. can be the major contributor for its inception. Nonetheless, viral infections at an early age are also found to trigger the onset of type I diabetes. In this review article, the history of the discovery of insulin is detailed along with the justification for the genetic and epigenetic regulatory mechanisms of diabetes and explained how viral infections can also trigger the onset of diabetes.
\end{abstract}

Keywords Autoimmunity $\cdot$ Diabetes $\cdot$ Enterovirus $\cdot$ Histone $\cdot$ Hyperglycemia $\cdot$ Insulin $\cdot$ Methylation

\begin{tabular}{|c|c|c|c|}
\hline \multicolumn{2}{|c|}{ Abbreviations } & GLUT4 & Glucose transporter type 4 \\
\hline ACE2 & Angiotensin converting enzyme 2 & GWAS & Genome wide association studies \\
\hline $\mathrm{ADH}$ & Antidiuretic hormone & HAT & Histone-acetyltransferases \\
\hline AIRE & Autoimmune regulator & $\mathrm{Hb}$ & Haemoglobin \\
\hline \multirow[t]{2}{*}{ APS 1} & Autoimmune polyglandular syndrome & HDAC & Histone-deacetylases \\
\hline & type 1 & HLA-I & Human leukocyte antigen-I \\
\hline $\mathrm{BACH} 2$ & Basic leucine zipper transcription factor 2 & IFIH1 & Interferon induced helicase 1 ; \\
\hline CGM & Continuous Glucose Monitoring System & IL2RA & Interleukin-2 receptor subunit alpha \\
\hline CVB & Coxsackievirus B & INS & Insulin gene \\
\hline DNMT & DNA methyl-transferases & IRS-1 & Insulin receptor substrate 1 \\
\hline DI & Diabetes insipidus & IUGR & Intrauterine growth retardation \\
\hline EGWAS & Epigenome-wide association study & LSD1 & Lysine specific demethylase- 1 \\
\hline ER & Endoplasmic reticulum & LYP & Lymphoid specific phosphatase \\
\hline \multirow{3}{*}{$\begin{array}{l}\text { EV } \\
\text { GLIS3 }\end{array}$} & Enteroviral & MDA5 & Melanoma differentiation-associated \\
\hline & Gli similar 3 protein & & protein 5 \\
\hline & & MEF2 & Myocyte enhancing factor 2 \\
\hline \multirow{2}{*}{\multicolumn{2}{|c|}{$\begin{array}{l}\text { Sumit Ghosh, Sushweta Mahalanobish and Parames C. Sil are } \\
\text { contributed equally to this work. }\end{array}$}} & MHC & Major histocompatibility complex \\
\hline & & MET & Metformin \\
\hline \multirow{2}{*}{\multicolumn{2}{|c|}{$\begin{array}{l}\text { Corresponding Editor: Somnath Paul; Reviewers: Aranyak } \\
\text { Goswami, Syed Benazir Firdaus, Partha Chakrabarti. }\end{array}$}} & MxA & Myxovirus resistance protein \\
\hline & & MyoD & Myoblast determination protein; \\
\hline \multirow{3}{*}{ 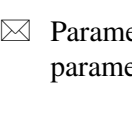 } & & NGS & Next generation sequencing \\
\hline & se.ac.in; parames_95@yahoo.co.in & NK & Natural killer \\
\hline & & OCT & Organic cation transporter family \\
\hline $\begin{array}{l}\text { Divisic } \\
\text { Schem }\end{array}$ & $\begin{array}{l}\text { lecular Medicine, Bose Institute, P-1/12, CIT } \\
\text { Kolkata, West Bengal 700054, India }\end{array}$ & PI3K & Phosphoinositide 3-kinase \\
\hline
\end{tabular}




\begin{tabular}{|c|c|}
\hline PTPN22 & $\begin{array}{l}\text { Protein tyrosine phosphatase non-receptor } \\
\text { type } 22\end{array}$ \\
\hline RNase, RIG-I & Retinoic acid inducible gene-I \\
\hline RNA & Polymerase \\
\hline SARS-COV-2 & $\begin{array}{l}\text { Severe acute respiratory } \\
\text { syndrome-coronavirus- } 2 \text {; }\end{array}$ \\
\hline SUF & Sulfonylureas \\
\hline T1D & Type I diabetes \\
\hline $\mathrm{T} 2 \mathrm{D}$ & Type II diabetes \\
\hline TDG & Thymine DNA glycosylase \\
\hline TEDDY & $\begin{array}{l}\text { The environmental determinants of diabe- } \\
\text { tes in the young }\end{array}$ \\
\hline TET & Ten-eleven translocation \\
\hline TZD & Thiazolidinediones \\
\hline UBASH3A & $\begin{array}{l}\text { Ubiquitin associated } \mathrm{SH} 3 \text { domain con- } \\
\text { taining protein A }\end{array}$ \\
\hline UPR & Unfolding protein response \\
\hline USF1 & Upstream transcription factor 1 \\
\hline VNTR & Variable number tandem repeats \\
\hline
\end{tabular}

\section{Introduction}

Looking at the past, it is very easy to understand that since the beginning of creation, man would have liked to make his life continually easier. Perhaps the emergence of science is the result of different arguments and thoughts and consciousness in the pursuit of that desire. In the present age, science has given us the gift of internet, smart phones, e-mail, and many more conveniences. Just as it is meaningless to live in this age without use of many of these things, similarly, it is difficult for a diabetic individual to live a simple and beautiful life without the wonderful invention of the twentieth century, "Insulin".

Diabetes mellitus, commonly referred to as diabetes, is not a disease confined to a definitive boundary, but a combination of many metabolic diseases. Insulin deficiency in our body is the main cause of diabetes. Insulin is secreted from the pancreas to help the cells of the body to take up glucose (sugar) from the blood, which normal cells can utilize to generate energy. The failure of the pancreas to generate enough insulin or the body's inability to use insulin properly, either of these or both in combinations can cause diabetes. The disease not only increases the amount of glucose level in the blood (hyperglycemia) but also abnormalities occur in the metabolism of proteins and fats [51]. Prolonged uncontrolled hyperglycemia initially causes changes in blood vessels and abnormal blood flow. As a result, different cells in the body undergo various changes; several complications arise in the body and the advancement of the diabetic condition continues. It should be noted here that the effects of this deadly disease are not limited to any particular organ; once established, it damages the function of most important organs of the body and without proper treatment those organs can become permanently paralyzed [50]. Notable among these are heart disease, stroke, diabetic retinopathy, kidney failure and anaemia $[20,21]$. This review briefly describes the various harmful aspects of diabetes, the ground breaking discovery of insulin, the role of insulin in the treatment of diabetes, the genetic and epigenetic aspects of the disease and the role of viral infections in triggering its onset.

\section{History of the discovery of insulin}

During the early years of reason, physicians would describe diseases in their own way and treat patients based on their knowledge of the surrounding ecology. Day after day, an almost sugar-free diet, sometimes $450 \mathrm{cal}$ or less per day (although more calories are needed to survive) in many cases pushed diabetic patients to death [37]. The discovery of insulin has undoubtedly put an end to thousands of years of extreme frustration and failure. Diabetes is one of the longest studied diseases in medical science. Probably, this disease was first mentioned in ancient Egyptian medicine since 1552 BC [120]. The word 'diabetes' was probably used first by the Greek physician Demetrios, meaning "siphon." Much later, in 1674, the British physician Thomas Wills named the disease "diabetes mellitus" to distinguish it from "diabetes insipidus" [82]. In 1776, Matthew Dobson, curious to see why some ants are being attracted to urine, turned his attention to this mystery. He later discovered that diabetic patients had high levels of sugar in their urine, so it tasted sweet, known as glycosuria [77].

During the period known as the "Pre-Insulin Age", or the "Age of Failure, and Depression," a list of the strangest foods was recommended to control the disease. Sugar-free diets, carbohydrate-controlled low-fat diets and starvation diets were particularly notable among the recommended food lists. However, no such treatment or diet has actually been of any use in curing diabetes [123].

\section{Challenging path of insulin discovery}

During the period between 335 and $280 \mathrm{BC}$, the Greek anatomist and surgeon Herophilus was the first to identify the pancreas gland in the human body, although it was named much later [120]. The endocrine gland was discovered by the German physician Paul Langerhans in 1869, which was later renamed as 'Isles of Langerhans', meaning the island of Langerhans. Langerhans first proposed presence of two types of cells in the pancreas, but he could not reveal the exact location and activity of those cells [73]. Later, in 1875, the German physiologist and histologist Rudolf Heidenhein, based on the experimental result, proposed that changes occur in the physiological structure of that gland 
when something is secreted. In 1884, Vaillard and Arnozan examined the lining of the pancreas and found that the pancreas was damaged after duct ligation, but there was no effect on the islets of Langerhans [9].

In 1889, two German physicians, Joseph von Mering and Oscar Minkowski, dissected out the pancreas of a dog and made it artificially diabetic. The next day they noticed that the dog had been micturating all day and the urine contained a lot of sugar. Thus, it was established that diabetes is caused by the absence of something within the pancreas [14]. Thereafter, scientists around the world began searching for the substance within the pancreas. While conducting experiments in this area, it was noted that the diabetic patients were not recovered after consuming pancreatic extract in various ways. On the contrary, poisoning effect was noted in some cases. In the midst of such an extreme despair, researchers revealed that the islets of Langerhans are performing a specific function that was completely different from the rest of the pancreas [25]. In 1906, pathologist Dewitt tied a cat's pancreatic duct to extract beneficial diabetic insulates from the islets of Langerhans. Although the insulate was not very effective, yet it was able to maintain glycolytic activity consistently [33]. Subsequently, in 1908, application of pancreatic alcohol extract to diabetic patients showed good results [8]. After reviewing the results of all these experiments, scientists from different countries univocally concluded in 1912 that even if the exocrine pancreas is damaged, hyperglycemia and glycosuria are escapable, but it is inevitable if the islet of Langerhans is destroyed. Thus, considering the importance of the islets of Langerhans, an attempt was made to separate it from the rest of the pancreas. Unfortunately, despite the tireless efforts of scientists in many parts of the world, the two entities were not yet successfully separated.

Eugene Gley, a French physiologist and endocrinologist, was inspired by the hypothesis that "Islets of Langerhans are able to resist glucose in the urine" proposed by the French histologist Gustav-Edward Lagus. He applied pancreatic extracts from a dog to a diabetic dog and noticed that the dog's hyperglycemia, glycosuria and other symptoms of diabetes were reduced significantly. The next question was, did the improvement in the diabetic dog come from the secretion of the islets of Langerhans or from the rest of the pancreas? To prove that, he injected islets of Langerhans tissue extract to a diabetic dog; as a result the dog was found to be in much better condition and its glycosuria and other symptoms of diabetes were significantly improved. After 25 years, Banting and Best repeated the experiment and insulin was discovered. However, at the end of the experiment Gley wrote a report in 1905 , sent the report in a sealed envelope to the Biological Society of France and instructed not to open it without his permission, even under pressure of higher authorities.
Gley never performed this test again after 1890 . When Banting and Best announced their discovery to the International forum in 1921, Gley ordered the envelope to be opened and realized that he had unknowingly invented insulin [120].

In the final step of the discovery of insulin, the credit actually conferred to four scientists. They were Banting, Best, McLeod and Collip. On October 20, 1920, as Banting was preparing to give a lecture on the 'Role of the pancreas in the carbohydrate metabolism', when he came across a research paper of Moses Baron in the November issue of the Journal of Surgery, Gynaecology and Obstetrics published by the University of Minnesota. During routine autopsy, Baron noticed a sporadic occurrence of stones in the pancreas. Even occasional was the fact that the stone blocked all the major ducts of the pancreas. Baron observed that the islets of Langerhans were not affected in any way, even though all of the acinar cells had been destroyed by the stone. After literature survey, he also realized that this phenomenon is comparable to the experimental results of tying the flow of pancreatic ducts. Studying the research of Baron with great care, Banting after reviewing the research done by Baron realized that when the ducts are open, i.e. under normal conditions, the digestive fluid of the pancreas absorbs the fluid from the islets of Langerhans; however this is not possible if they are closed. Banting, therefore, concluded that the destruction of various pancreatic cells starts after a while when the pancreatic duct was closed. Nonetheless, insulin was found in the fluid secreted from the remaining portion of what remained i.e., islets of Langerhans. Banting knew very little about the prior efforts made by different scientist to discover insulin and their failure and illusion. Such ignorance helped him to remain committed to his ideas [10, 124].

F. R. Miller, the Head of the Department of Physiology, who knew about Banting's hypothesis, advised him to go to John James Richard McLeod and express his new ideas. McLeod was a professor of physiology at the University of Toronto. Moreover, he was also a leading scientist in the study of sugar metabolism. Banting first met McLeod on November 7, 1920, but after talking to Banting, McLeod realized that Banting was of limited merit; he did not know much about the proceedings in the world of science and was only a scholar of biblical knowledge. He discouraged Banting, informing him that many eminent scientists could not isolate this hormone (insulin) despite many attempts. Banting returned back disappointedly, but few days later he met McLeod again. Eventually McLeod agreed, perhaps realizing Banting's huge past experience of surgery in the war camp during World War I. Therefore, Banting could be able to excise much efficiently, the duct of the pancreas of a normal dog replacing it to another diabetic dog. Moreover, many former researchers tried but all of them failed to 
observe the end result i.e., when all digestive cells in the pancreas were damaged $[56,116,124]$.

During this time, two assistant students, Charles Herbert Best and Edward Clark Noble, joined his laboratory as demonstrators in the hope of obtaining a Master of Arts (MA) degree. McLeod introduced them to Banting and instructed them to help Banting to prove his hypothesis [80, 124]. Banting and Best did a great job together, both of whom were aware and respectful of the techniques of the two and an effective bond was established [108].

Work began on May 17, 1921. Insulin was discovered within a few days in the Department of Physiology at the University of Toronto. Under McLeod's guidance, the two demonstrators began their research with great care. McLeod went on a holiday to Scotland on 14th June, informing them of all the means of communication. At first, they ligated an already dissected dog's pancreas and stored it in the cold. After the duct system of the pancreas was completely destroyed, they placed it inside a diabetic dog through surgery. As a result, the dog recovered [112].

When McLeod returned from vacation on September 21 , he could not believe that the research had progressed so far. He questioned the accuracy of their information. Banting was always in a bad mood and used to talk to others with disrespect. So, McLeod was utterly humiliated by his behaviour and could no longer restrain himself. As a result, various bitter arguments started. In fact, McLeod wanted the two of them to repeat all the work done; they started insulin purification so that the results could be confirmed. $\mathrm{He}$ also explained to them a special test to prevent the blood sugar from falling due to the effects of dilution. Banting then wanted a separate room to continue his research work and a helper to look after the dogs. Moreover, he also requested a certain amount of salary for himself. When McLeod refused, Banting threatened to give up the job and move to the Mayo Clinic or the Rockefeller Institute. At first, McLeod did not pay much attention to his departure, but after a couple of days, he had realized his importance for continuing the work, and finally accepted Banting's terms. Banting then asked McLeod if biochemist J. B. Collip could join their team. McLeod advised not to expand the team at that time. Finally, Banting resumed his work with Best. The repeat experiments were done precisely and they got the same result. McLeod was convinced with the result, yet realized that there was still much work needed to be done although Banting wanted to move forward for the clinical tests. At this point of time, McLeod accepted Banting's request to include Collip in their research team. The responsibility given to Collip was to purify the insulin-carrying extract from the dog's ductless pancreas as much as possible so that the pure extract could be applied to the diabetic patient as needed. It is worth mentioning here that Collip was experienced in healing animals by injecting fluid from different glands [124, 125].
Finally on January 11, 1922, Banting, Best, McLeod and Collip, all were ready to inject insulin into the body of a 14-year-old diabetic patient, named Thompson. Unfortunately, there was no permission for Banting, Best or Collip to be present in person at the Toronto Medical School, where $15 \mathrm{ml}$ of pancreatic extract was injected to Thompson's body. However, one of the symptoms of diabetes, i.e., ketoacidosis (increase in the level of ketone bodies in the blood due to diabetes) did not change. The level of glycemia and glycosuria decreased a little. Conversely, various toxicities (e.g., sterile abscesses) also occurred at the injection site. Thus, the first clinical trial failed. Everyone was very disappointed! Collip could not accept the failure and worked hard to purify the insulin extract, the treatment began again on January 23 , 1922 by injecting the purified extract to Thompson's body. He began to improve as a result of daily injections. The ketone bodies disappeared from the urine, the blood sugar level dropped and he started to look much brighter. His ability to work also began to increase. In fact, it was the first successful experiment on diabetic humans based on the internal secretions of the pancreas. Thompson was the first person in the world to return to normal life with diabetes. The news spread like wildfire all over the world. Banting and McLeod were awarded the Nobel Prize in 1923, the very next year, in recognition of such research for the welfare of the human race. Unfortunately, Best and Collip were deprived for this award. Banting could not accept the omission of Best; he immediately announced that he would give half of his prize money to Best. Likewise, McLeod paid half of his reward money to Collip [10, 108].

\section{Commercial production and beginning of chemical synthesis of insulin}

Subsequent to the discovery of insulin, attempts were made to produce insulin commercially around the globe. The University of Toronto licensed pharmaceutical companies to produce insulin without royalties. Within a year of the first injection, people around the world began receiving insulin. Insulin took a special place among the earliest notable proteins. Abel generated a pure crystal of this protein in the year 1926 [49]. With the help of X-ray crystallography, the scientists were able to know the three-dimensional shape of insulin from that crystal and how insulin works with other molecules in the body. In 1955, Frederick Sanger successfully determined the full amino acid sequence of this protein and was awarded the Nobel Prize in 1959 in recognition of his work (Table 1). In fact, insulin was the first protein to be chemically synthesized in a laboratory in 1963 [106]. Notably, even ninety years after the discovery, diabetics still rely primarily on insulin derived from the pancreas of other animals. Although insulin of other animals work well on the whole, their composition is slightly different from that 
Table 1 Timetable of events related to insulin discovery

\begin{tabular}{lll}
\hline Year & Research team & Discovery \\
\hline 1776 & Matthew Dobson & Diabetic patients exhibit glycosuria \\
1869 & Paul Langerhans & Isles of Langerhans in pancreas \\
1875 & Rudolf Heidenhein & Physiological structure of pancreas change after secretory activity \\
1884 & Vaillard \& Arnozan & Islets of Langerhans unaffected after duct ligation \\
1889 & Joseph von Mering \& Oscar Minkowski & Diabetes is caused by the absence of something within the pancreas \\
1890 & Eugene Gley & Islets of Langerhans tissue extract reduces hyperglycemic complications \\
1920 & Moses Baron & Islets of Langerhans not affected due to duct blockade by pancreatic stone \\
1921 & Frederick Banting, Charles Best, James Collip & Discovery and purification of insulin \\
1922 & Frederick Banting, John McLeod, Charles Best, & Insulin extract successfully reduces diabetic complications in a 14 year old patient \\
1926 & James Collip & Pure crystal of insulin \\
1955 & Fohn Abel & Full amino acid sequence of insulin \\
\hline
\end{tabular}

of human insulin, so occasional side effects (such as rashes) do occur.

\section{Biotechnological interventions to produce human insulin}

In 1978, human insulin was produced as the first protein with the help of biotechnology. Subsequently, in 1997, the FDA (Food and Drug Administration) allowed the use of modified insulin (named insulin lispro or Humolog) that is specifically formulated to work immediately after injection.

Modified insulin gene developed in the laboratory, inserted into a loop of bacterial DNA called plasmid and transfected into a bacterium generates the recombinant bacterium. Such recombinant bacteria placed in fermentation tanks produce insulin using the inserted gene. This insulin is harvested and purified for medical use. Insulin preparations using recombinant DNA technology began in the 1980s. It was one of the first instances of generation of a substance for medicinal purpose using technological innovation. Insulin aspart or NovoRapid is generated in Saccharomyces cerevisiae via recombinant DNA technology [119].

The insulin analogues later approved for human use were aspart insulin (NovoRapid), glargine insulin (Lantus), glulisine insulin (Apidra), detemir insulin (Levemir) and inhalable insulin, Exubera \& Afrezza, in 2000, 2000, 2004, 2005, 2006 and 2014 respectively [104]. "Degludec Insulin" was withdrawn from the market in 2013 for severe side-effects with other drugs, but in 2015 it was again allowed to use with some changes in its composition [39].

In 2019, a team of researchers at MIT, US have discovered an insulin capsule that can be used like any other capsule [43]. If it gets FDA approval, type 1 diabetic patients will be able to take this capsule every day instead of injections.

\section{Genetic regulations of diabetes}

\section{Type I diabetes}

Type I Diabetes (T1D) is associated with pancreatic $\beta$-cell destruction mediated insulin deficiency [102]. T1D is associated with some modes of autoimmune destruction mediated diabetes [55]. Autoimmune diabetes is sometimes associated with genetic mutation mediated alterations in immune functions. For example, autoimmune polyglandular syndrome type 1 (APS1) is initiated by the mutation of the autoimmune regulator (AIRE) gene and is symptomatically linked with T1D $[1,55]$. On the other hand, mutation of the STAT3 gene may lead to polyautoimmunopathy and is associated with autoimmune neonatal diabetes [43].

T1D exhibits $1.3-4 \%$ risk in the children of female diabetic patients and a 6-9\% risk in the children of male diabetic patients $[36,88]$. The risk of T1D is $70 \%$ higher in identical twins than non-identical ones [103]. In T1D, the rate of affected children varies greatly; 0.1 per $100,000 /$ year in China \& Venezuela and 40.9 per 100,000/year in Finland [34]. In Sardinia, a high rate of occurance of such phenomena has been reported, an observation discordant in respect to the whole of Italy. Several European countries and different parts of North America have been reported to show high or moderate rate of such incidence. In Asia, it is considerably low. Though T1D can be elicited at any stage of life, but its exhibits elevated rate of onset from birth to 14 years of age. The occurrence of this disease is increased in low income countries. Environmental factors play an important role in islet autoimmunity. Therefore, improvement of living standards enhances the chance of development of autoimmunity. The incidence of this disease is associated with seasonal changes with highest incidence in winter and autumn [85]. 
Chromosome $6 \mathrm{p} 21$ bears the HLA region which imparts $50 \%$ of the familial accumulation of T1D. Other than the HLA region, insulin gene (INS) exhibits a strong association with T1D. Chromosome 11p15 bears INS and the region exhibits polymorphisms by virtue of 3 variable number tandem repeats (VNTR). These polymorphisms control the level of insulin mRNA in the thymus and influences immune tolerance towards insulin [100,118].

Several genetic polymorphisms are linked with T1D. The protein tyrosine phosphatase non-receptor type 22 (PTPN22) gene on chromosome $1 \mathrm{p} 13$ exhibits polymorphisms and encodes lymphoid specific phosphatase (LYP) [93]. LYP suppresses activation of T cells and is linked with T1D [68]. On the other hand, the interferon induced helicase 1 (IFIH1), interleukin-2 receptor subunit alpha (IL2RA), ubiquitin associated $\mathrm{SH} 3$ domain containing protein A (UBASH3A) and basic leucine zipper transcription factor 2 (BACH2) are important genetic loci associated with T1D [23, 24, 114, 121]. Additionally, the Gli similar 3 protein (GLIS3) genetic locus is also linked to neonatal diabetes and T1D [11]. It is associated with the generation and apoptosis of pancreatic $\beta$ cells and the expression of INS [91].

Next Generation Sequencing (NGS) helps in the identification of most of the genetic variants observed in the genome of an individual, irrespective of their respective frequencies. It is a more powerful tool than Genome Wide Association Studies (GWAS). Several studies related to NGS applications in T1D have been carried. For example, (1) NGS has led to the identification of HLA-DRB 3,4,5 to be associated with increased risk of T1D in children, (2) NGS has identified HNF1B and K-ATP channel genetic variants to be more involved with monogenic diabetes $[35,134]$.

\section{Type II diabetes}

Type II Diabetes (T2D) is associated with a reduction in insulin sensitivity or insulin resistance mediated hyperglycemic condition. In T2D, detection of onset of the disease is difficult. Lack of noticeable acute metabolic disturbance (as observed in type 1 diabetes) makes the detection of early onset of the disease quite problematic, thereby resulting in about one half of the population remaining undiagnosed. In rural areas, the number of affected individuals is relatively low compare to urban populations with western lifestyles. According to thrifty gene hypothesis, increased chances of deposition of fat and T2D are observed in individuals migrating from a region of food scarcity to an area of food abundance. In UK, the number of diabetic South Asian and African Caribbeans is high in number compared to European populations [44]. There is no significant sexual biasness in affected individuals and the chance increases along with advancement of age [45].
Applications of NGS to T2D patient samples have led to various advances in research. Some of them are: (1) mapping of rare as well as common genetic variants (e.g., identification of COBLL1 and MACF1 from Danish population studies), (2) identification of epigenetic markers (e.g., TCF7L2 as blood biomarker), (3) RNA-Seq mediated transcriptional profiling of cellular and tissue samples (e.g., identification of miR-375 RNA affecting genes of pancreatic islets), etc. $[4,41,89,126]$.

For the treatment of T2D, metformin, sulfonylureas/ glinides, thiazolidinediones and GLP-1 receptor agonists/ DPP-4 inhibitors are used. Genome wide association studies (GWAS) have provided strong connection of gene-drug interactions. The variants of organic cation transporter family (OCTs) encoded by SLC22A1 of chromosome 6q25.3, ATM of chromosome 11q22.3, and SLC2A2 loci of chromosome 3q26.2 are associated with Metformin (MET) response; CYP2C9 of chromosome 10q23.33, TCF7L2 of chromosome 10q25.2/10q25.3, ABCC8 of chromosome $11 \mathrm{p} 15.1, \mathrm{KCNJ} 11$ of chromosome $11 \mathrm{p} 15.1$ and IRS1 loci of chromosome 2q36.3 are associated with sulfonylureas/ glinides (SUF) response; PPARG locus is associated with thiazolidinediones (TZDs) response; and GLP1R locus is associated with GLP-1 receptor agonists/DPP-4 inhibitors response [81]. Such pharmacogenomic studies help in the identification of drug responses associated with allelic variants and holds immense potential in catalyzing tailored therapies.

Homozygotic carriers of a loss of function mutation of TBC1D4 exhibits a tenfold higher risk of T2D among Inuit populations of Greenland. The mutant allele carriers bear low concentration of glucose transporter type 4 (GLUT4) in their skeletal muscles than the non-carriers $[72,86]$. Thus, inadequate GLUT4 mediated glucose uptake during postprandial hyperglycaemia increases the risk of T2D. On the other hand, exome sequencing has led to the detection of a loss of function mutation in ADCY3 which is associated with obesity and diabetes in the same Inuit population [54]. Several T2D susceptibility variants observed in various populations include that of GRB10, BCL2, FAM19A2, NAT2, PPAR $\gamma$, IRS-1, TCF7L2, TCERG1L, SC4MOL, ARL15 and PPP1R3B [5, 17, 26, 29, 61, 65, 67, 78, 99, 111, 122].

Machine learning techniques can be used for predicting disease susceptibility among populations. In a recent study, decision tree (WEKA), random forest (WEKA) and neural network (MATLAB) techniques were used for the prediction of diabetes mellitus in a Chinese population. There were 14 chosen attributes: age, breathe, pulse rate, left systolic pressure (LSP), height, right systolic pressure (RSP), left diastolic pressure (LDP), weight, right diastolic pressure (RDP), waistline, physique index, low density lipoprotein (LDL), fasting glucose and high density lipoprotein (HDL). It was observed that fasting glucose exhibited better performance 
in test results. Therefore, it is an important index for prediction. However, due to the nature of the data set, the type of diabetes could not be predicted [136]. Further advancement of research in this field holds potential in unveiling methods for the accurate prediction of diabetic onset (T1D or T2D) based on data of genetic susceptibility markers.

\section{Epigenetic influence in diabetes}

Epigenetics refers to the heritable changes of gene expression under environmental influence without altering DNA sequence [15]. Environmental factors control the activation or inhibition of a particular gene expression by regulating transcription factor accessibility to DNA. Among epigenetic modifications, DNA methylation, histone modifications and altered microRNA mediated genetic expression trigger the onset of several autoimmune disorders including T1D [68]. The main environmental factors responsible for onset of T2D are intra-utero environments, advancement of age, low birth weight, obesity of mother that ultimately cause intrauterine growth retardation (IUGR) of child [63]. The impacts of IUGR on adulthood lead to pancreatic abnormalities by interfering in cells proliferation, differentiation, and maturation that cause onset of T2D.

\section{DNA modifications in T1D}

\section{DNA methylation}

During DNA methylation, DNA methyl-transferases (DNMT) catalyse the addition of methyl group on the fifth carbon cytosine in the $\mathrm{CpG}$ island to form 5-methylcytosine [66]. Basically, DNMT1, DNMT3a, and DNMT3b are responsible for this conversion [31]. DNMT1 causes methylation of newly synthesized un-methylated daughter strands during DNA replication to keep methylation pattern of genome in check. On the other hand, DNMT3a and DNMT3b are essential for de novo DNA methylation process. On the contrary, in the process of DNA demethylation, oxidation of 5-mC and thymine DNA glycosylase (TDG) mediated removal of modified base generates cytosine occurs by replacing 5-mC. Additionally, a family of teneleven translocation (TET) methyl-cytosine dioxygenases are also involved in the process of demethylation [69]. Altered methylation status of DNA changes the expression profile of genes related to insulin secretion, beta cell survival, and autoimmunity and therefore trigger the onset of T1D [137]. In a particular study, genome wide methylation profiling of monozygotic (MZ) twins showed discordancy of T1D due to T1D related methylation of genes regulating inflammation, immunity, and apoptosis. Moreover, there were $88 \mathrm{CpG}$ sites showing differential methylation in T1D-discordant MZ twin pairs. In pancreatic $\beta$ cells and thymic epithelial cells, methylation of INS gene promoter is associated with T1D onset [47, 109]. Heavy methylation at CpG-69, -102, -180, -206 and low methylation at $\mathrm{CpG}-19,-135$, and -234 in INS gene has been found in patients with T1D compared to healthy controls. Pro-inflammatory cytokine mediated methyl transferase activation causes methylation of Ins1 exon-2 and Ins2 exon-1 which control the expression of INS gene. Besides INS gene, epigenetic modulation of Interleukin 2 receptor a-chain gene (IL2RA) also initiates T1D development. High expression of Interleukin 2 receptor on regulatory $\mathrm{T}$ cell surface suppresses the auto-reactive T cells activity. High methylation of IL2RA CpGs-373 and -456 in T1D patients generates autoimmunity [13]. Various complications associated with T1D like diabetic nephropathy are also regulated by epigenetic modulation. In T1D patients, methylation $\mathrm{CpG}$ site near transcription start site of UNC13B gene triggers the onset of diabetic nephropathy [12].

\section{Micro-RNA modifications}

The micro-RNAs (miRNAs) are single stranded non-coding RNA molecules that act as RNA silencer and thereby act as post-transcriptional regulator [115]. Inside the nucleus, in the presence of RNA polymerase (RNase) II and III, primary miRNA is transcribed and processed to precursor miRNA with the help of Drosha/DGCR8. After being released in the cytoplasm, it is finally converted to mature miRNA by RNase III dicer complex [22]. Mature miRNAs bind to 3' UTR of targeted mRNA, and repress protein production by destabilizing target mRNA [40]. miRNAs play an important role in controlling cellular processes like proliferation, differentiation, glucose homeostasis, apoptosis, carcinogenesis, inflammation etc. The association of miRNAs with the production and secretion of insulin is well documented [57]. In T1D, altered miRNA levels affect insulin secretion, immuneregulation and the mitogen-activated protein kinase (MAPK) signaling pathway [6]. During proliferation of $\beta$-cells, some of the miRNAs show positive impact while others exhibit negative impact. miR-375 targets various growth inhibiting genes to control $\beta$-cell proliferation [76]. miR-375 knock out mice exhibits diminished $\beta$-cell mass as miR-375 inhibits the activity of Cadm1 which represses G1/S transition and cellular growth [98]. Similarly, miR-181a exhibits protective effects by inducing $\beta$-cell proliferation [133]. On the other hand, increased expression of miR-24 in db/db mice is associated with the aging of the mice [135]. miR-29a inhibits proliferation of INS-1E cells (pancreatic islet $\beta$ cells) and diminished insulin secretion from $\beta$-cell [7]. Although miR29 has an important role in $\beta$-cell proliferation, it can negatively control insulin secretion by targeting Stx-1a which is associated with insulin exocytosis [52]. miR-155-5p upregulation in human islet derived exosomes targets mRNA of the 
transcriptional and immune response regulator gene. This miR-155-5p also evokes inflammatory response in T1D by interacting with toll-like receptors, resulting in the activation of the NF-kB pathway [48]. miR-146a-5p negatively regulates IL-6 activity whereas in T1D, low level of miR146a-5p expression is associated with increased IL-6 production. Therefore, miR-146a-5p can control inflammation by negative feedback effect on NF- kB and its low level activity in T1D triggers inflammation [92]. Furthermore, in T1D patients, upregulated expression of miR-23b, miR98, and miR-590-5p in cytotoxic CD8+T cells suppress the function of various apoptotic gene (like TRAIL, FAS) and facilities survival and enhanced proliferation of auto-reactive T lymphocytes [28].

Circulatory miRNA can be used as a potential biomarker for early detection of T1D. Increased expression of circulating miR-125b-5p and miR-365a-3p is associated with increased $\mathrm{HbA} 1 \mathrm{c}$ level (glycated haemoglobin) whereas urinary miR-377 is positively correlated with upsurge HbA1c level and urinary albumin creatinine ratio of T1D patients [38].

\section{Histone modifications}

Histones modifications refer to post translational modification of histone protein by various processes like methylation, acetylation, phosphorylation, ubiquitination, and sumoylation. In histone methylation, methyl group addition to arginine or lysine residues leads to the activation or suppression of transcription based on the degree of modification whereas, in histone demethylation, lysine specific demethylase-1 (LSD1) demethylated mono- and di- methylated lysine, specially H3K3 and H3K4 region [68, 107]. The histone acetylation and de-acetylation indicate addition or removal of acetyl group with the help of histone-acetyltransferases (HATs) and histone-deacetylases (HDACs), respectively. Histone acetylation increases the accessibility of transcription factor to the DNA by opening the chromatin structure via reduction of electrostatic attraction between DNA and histone [53].

Modification of histone protein alters the chromatin structure that causes the onset of various pathophysiological conditions including T1D. In T1D patients, increased H3 lysine-9 di-methylation (H3K9me2) was found in CLTA4 gene and other genes related to auto-immunity and inflammation. Moreover, huge variation in H3 lysine-9 acetylation $(\mathrm{H} 3 \mathrm{~K} 9 \mathrm{Ac})$ in the upstream regions of HLA-DRB1 and HLA-DQB1, is intensely associated with T1D [84]. In T1D patients, increased level of $\mathrm{H} 4$ acetylation compared to T1D patients with cardiovascular complications indicates that histone acetylation may protect against T1D associated complication development [18].

\section{DNA modifications in T2D}

\section{DNA methylation}

The process of DNA methylation in the islets depends on methylation of lysine 9 on $\mathrm{H} 3$ (H3K9) by the enzyme DNA methyl-transferase [110]. This causes the epigenetic change in IUGR islet where HDAC/mSin $3 \mathrm{~A}$ complex interaction with $\mathrm{Pdx} 1$ leads to deacetylation and inhibits $\mathrm{Pdx} 1$ transcription and resulting in pancreatic agenesis [62]. Although minor Pdx1 protein level depletion does not affect usual $\beta$ cell mass, it impairs $\beta$ cell insulin secretion activity. Epigenome-wide association study (EGWAS) shows that methylation on $\mathrm{CpG}$ site in ABCG1 gene present on 21 st chromosome is linked with insulin resistance. This methylation on ABCG1 is associated with fasting insulin and can therefore be used as a disease marker [58]. EGWAS analysis on Indian populations suffering from T2DM shows that methylation of ABCG1, PHOSPHO1, SOCS3, SREBF1, and TXNIP is associated with early incidence of T2DM [16]. DNA methylation at the ABCG1 locus cg06500161 of DNA is positively correlated with $\mathrm{HbA} 1 \mathrm{c}$, fasting insulin, and triglyceride levels in the blood of diabetic twin among monozygotic twins which are discordant for T2D. DNA methylation at PHOSPHO1 locus cg02650017 is positively associated with HDL levels in diabetic in comparison to non-diabetic monozygotic twins [27]. In Mexican American populations, methylation of TXNIP, ABCG1 and SAMD12 is responsible for heritability of T2D [70].

Modification of histone protein activity in IUGR rat muscle indicates insulin resistance $[62,94]$. Under normal conditions, transport of glucose from blood to cell followed passive diffusion with the help of GLUT4 mainly in adipose tissue, skeletal muscles, and cardiac muscle [64]. The expression of GLUT4 is regulated by myoblast determination protein (MyoD) and myocyte enhancing factor 2 (MEF2) factors [87]. Upregulated expression of MEF2D and downregulated expression of both MYoD and MEF2A cause repressed GLUT4 expression. Another pathway that controls IUGR GLUT4 transcription was H3K14 (histone 3 lysine 14) deacetylation. HDAC1-HDAC4 mediated deacetylation of $\mathrm{H} 3 \mathrm{~K} 14$ facilitates the recruitment of the suppressor of variegation 3-9 homolog 1 (Suv39H1) methylase that causes $\mathrm{H} 3 \mathrm{~K} 9$ dimethylation and increased attachment of heterochromatin protein 1 . This leads to IUGR GLUT4 gene repression [101]. These indicate perinatal nutrition deficiency mediated IUGR leads to histone modification that eventually decreases GLUT4 expression and glucose transportation inside the cells. Figure 1 represents various genetics and epigenetics reasons of Type 1 and Type 2 diabetes. 


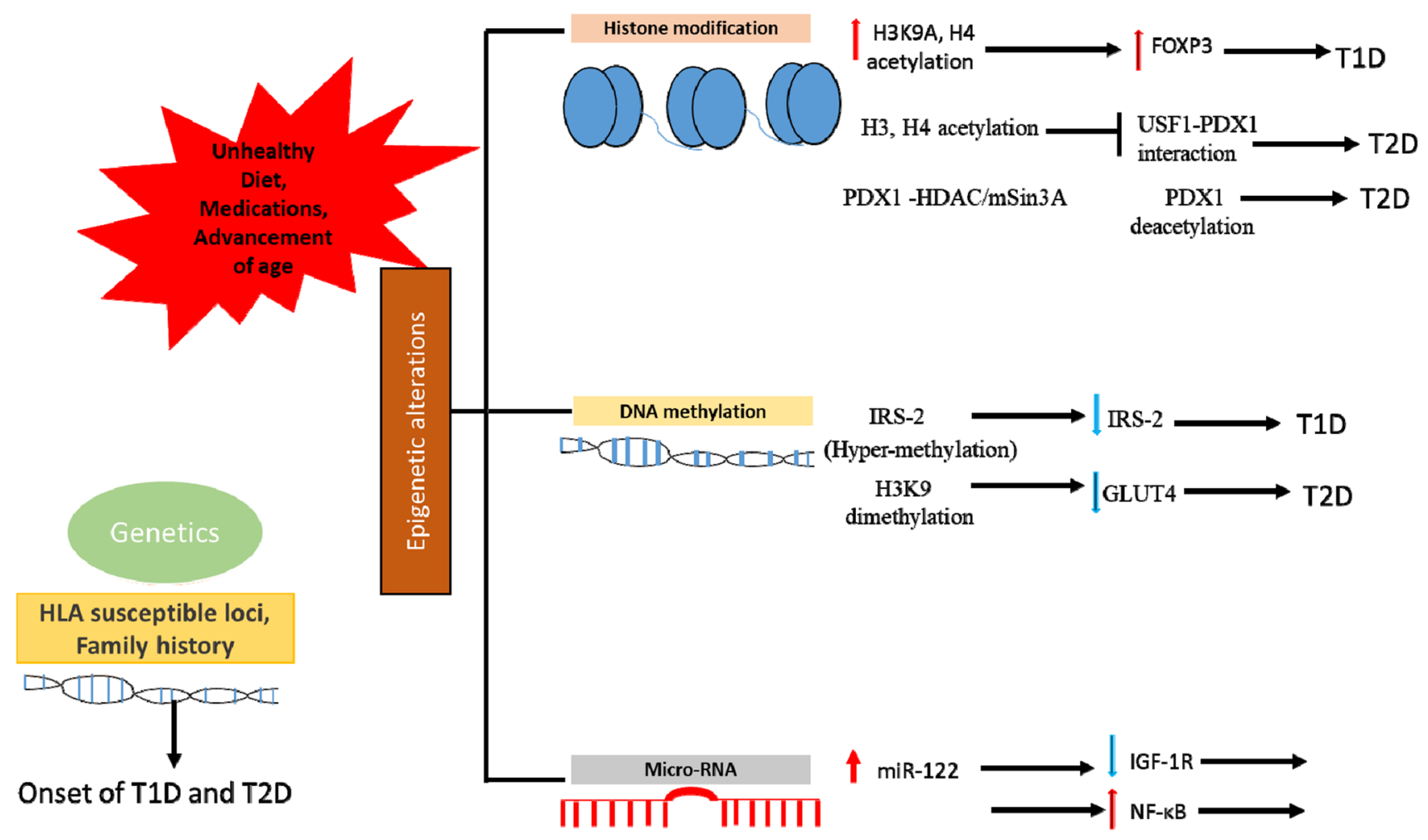

Fig. 1 Flow diagram depicting various genetics and epigenetics reasons of Type 1 and Type 2 diabetes

\section{Micro-RNA modifications}

During T2DM, miRNAs effectively control insulin signalling and insulin resistance (IR) [41]. Interaction between ligand and receptor is crucial for insulin signalling. Elevated expression of miR-195 and miR-15b causes downregulation of insulin receptor by binding to its 3'-UTR site and resulting in signalling disruption [129, 131]. Increased expression of miR-29a suppresses insulin receptor substrate 1 (IRS-1) by directly interacting with its 3 '-UTR site [130]. Overexpression of miR-103/107 interferes with IRS- 1 and caveolae (Cav-1) interaction and decreases IRS-1 stability [117]. In IRS-1-deficient condition, IRS-2 acts as an alternative substrate and interaction of its 3'-UTR with miR-135a negative impacts insulin signalling [2].

To predict the early onset of T2DM, the presence of miRNAs in the circulation is a reliable biomarker. It has been found that plasma miR-126 is associated with T2DM. It is the only mRNA whose activity is decreases in T2DM patients [132]. Moreover, on comparison of miRNA expression profile between pre-diabetic and T2DM individuals, miR-320b, miR-1249, and miR-572 have been found to be potential biomarkers for early detection of T2DM [128]. Advancement of T2DM triggers the onset of various health complications. Among them, in diabetic nephropathy (DN), expression profile of $\mathrm{miR}-29 \mathrm{a} / \mathrm{b} / \mathrm{c}, \mathrm{miR}-21$, and $\mathrm{miR}-192$ is upregulated [19]. During DN, miR-21 causes PTEN suppression, while miR-29c inhibits SPRY1 expression that regulates mesangial matrix accumulation and albuminuria in diabetic murine models [74, 79]. Interestingly, another type of miRNA that may serve as a candidate marker for DN are urinary miRNAs. Aberrant urinary miR-320c, isolated from urinary exosomes, may impact the TGF- $\beta$ signalling pathway by targeting THBS1 and can be used as a novel marker for disease progression in DN [30].

\section{Histone modification}

Pdx 1, a homeodomain-containing transcription factor, plays a key role in early generation of both exocrine and endocrine pancreas and on $\beta$ cell development in later stages. In IUGR rats, there was the repression of $\mathrm{Pdx} 1$ expression gradually after birth due to epigenetic alteration. In IUGR rat, isolated $\beta$ cells from pancreas showed the reduced level of histone acetylation in $\mathrm{H} 3$ and $\mathrm{H} 4$ at $\mathrm{Pdx} 1$ promoter [96]. Decreased acetylation of $\mathrm{H} 3$, and $\mathrm{H} 4$ hinder the interaction of upstream transcription factor 1 (USF1) to the promoter region of PDX1. USF1 is crucial for PDX1 transcription and reduced USF1 PDX1 interaction causing transcriptional silencing of PDX1 [113]. In IGUR rat, increased histone deacetylation along with decreased trimethylation of $\mathrm{H} 3 \mathrm{~K} 4$ and increased H3K9 dimethylation caused chromatin gene repression [96]. 
These factors altogether disrupt glucose homeostasis and upsurge oxidative stress in IUGR.

\section{Viral infection and type I diabetes}

Viral infection leads to the activation of antigen presentation and release of inflammatory cytokines. Molecular mimicry, inflammatory cytokines, repeated viral infections, induction of Class I Major Histocompatibility Complex (MHC) and the localized release of interferons induce the autoreactive effector T cell mediated destruction of pancreatic $\beta$ cells and cause enhancement of T1D. On the other hand, sequestering of effector $\mathrm{T}$ cells or their elimination by inflammatory cytokines from the pancreatic islets during acute or chronic infections and repeated infection mediated accumulation and viral persistence directed induction of protective regulatory $\mathrm{T}$ cells prevent the destruction of pancreatic $\beta$ cells and cause the abrogation of T1D. Thus, viral infections at an early age can trigger the onset of T1D (Fig. 2) [42].

Viral infection of pancreatic $\beta$ cells mediated inflammation and dysglycemia can elicit oxidative and endoplasmic reticulum (ER) stress mediated changes in cellular proteins through carbonylation, alternative splicing, deamidation, initiation of defective ribosomes, phosphorylation, citrullination, sumoylation etc. This promotes the generation of neo-epitopes which elevate the immunogenicity of the $\beta$ cells and the responses of autoreactive T and B cells [97].

Enteroviral (EV) infection can lead to destruction of pancreatic $\beta$ cells by directly killing them or by eliciting inflammatory response in the pancreatic islets to attract autoreactive $\mathrm{T}$ cells at the site of inflammation [105]. The viral persistence and high viral load mediated responses include upregulation of melanoma differentiation-associated protein 5 (MDA 5), myxovirus resistance protein (MxA), human leukocyte antigen-I (HLA-I), retinoic acid inducible gene-I (RIG-I) etc. EV infection leads to the release of interferons and the induction of ER stress and unfolding protein response (UPR) activity. Inflammatory cytokines and EV antigens lead to the development of adaptive autoimmunity, which in turn, further augments destruction of pancreatic $\beta$ cells [3]. This promotes T1D.

Viruses associated with T1D include enteroviruses like coxsackievirus B (CVB), rotavirus, mumps virus, cytomegalovirus and rubella virus with varying degrees of pathogenicity [32, 46, 59, 60, 83, 95].

TEDDY (The Environmental Determinants of Diabetes in the Young) analyses assess the effect of environmental factors like viral infections in the onset of autoimmune diabetes. It demands monitoring of children during any viral infection for higher genetic risk of T1D [42].

SARS-COV-2 infection has the potential to destroy pancreatic $\beta$ cells, reduce insulin secretion and induce T1D. On the other hand, treatment of SARS-COV-2 infected patients, suffering from hyperglycemia, with steroids, induces hyperinflammation, insulin resistance (T2D) and severity of COVID-19 symptoms [71]. SARS-COV-2 infection increases the level of inflammatory cytokines, lipopolysaccharides and Natural Killer (NK) cells, which lead to lung fibrosis and acute lung damage. It also induces

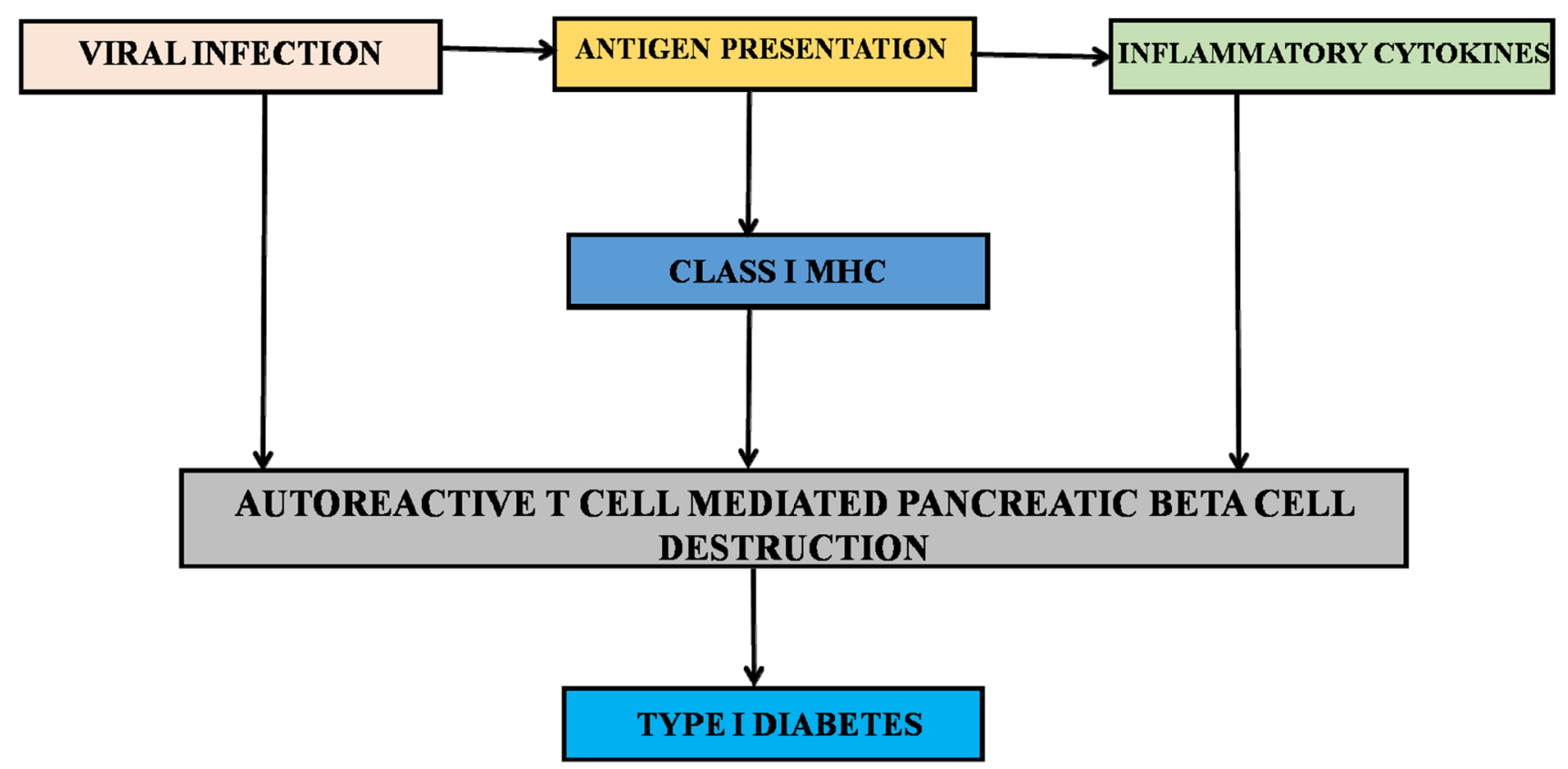

Fig. 2 Flow diagram showing different means of viral infection may lead to Type I diabetes 
oxidative stress mediated hyperglycemia and angiotensin II mediated insulin resistance [75]. SARS-CoV-2 enters the host cell through the angiotensin converting enzyme 2 (ACE2) receptor, thereby disrupting ACE2 mediated catalysis of the conversion of angiotensin II to angiotensin (1-7) [90]. The elevated level of angiotensin II inhibits the insulin dependent activation of phosphoinositide 3-kinase (PI3K) pathway and disrupts translocation of Glut-4 in insulin-sensitive tissues, thereby resulting in systemic insulin resistance [127]. The hyperglycemic condition leads to further progression of lung pathophysiology.

\section{Conclusion}

The history of the discovery of insulin is a fascinating story of sacrifice, patience, toil, solving complex observational scientific riddles and occupational complexities. It is an inspiration for future researchers in the field of protein biology, drug discovery and other aspects of pharmacology. Based on the present global situation in relation to the disease, the genetic and epigenetic regulations of diabetes need to be studied with utmost care and importance. While genetic predisposition analyses cater to a deterministic path, the epigenetic studies address the stochastic and selfcontrollable triggers of the disease. Since genetic regulation is one of the major contributors for T1D, lifestyle itself is a major factor for T2D and the medics need to address the patients accordingly for a proper cure. Recent studies have also revealed that viral infections at an early stage can also contribute to the onset of the disease in some individuals. More extensive research in the discussed fields is still awaiting.

Finally, let's go back to that old saying in a new way and say that there is no substitute for research on various topics, whether it is diabetes or something else, for us to live a beautiful and healthy life. As new problems come along, new research paths open up with the blessings of logic and science. The pursuit of science with relentless effort and endless patience, which people could not have imagined before, will easily come under our control and make the path of the next generation easier and more beautiful.

Acknowledgements The authors acknowledge University Grants Commission (UGC) and Council of Scientific \& Industrial Research (CSIR) for their support and guidance.

Funding No funding was required for this review work.

\section{Declarations}

Conflict of interest The authors declare that they have no conflict of interest.

\section{References}

1. Aaltonen J, Björses P, Perheentupa J, Horelli Kuitunen N, Palotie A, Peltonen L, Lee YS, Francis F, Henning S, Thiel C. An autoimmune disease, APECED, caused by mutations in a novel gene featuring two PHD-type zinc-finger domains. Nat Genet. 1997;17:399-403.

2. Agarwal P, Srivastava R, Srivastava AK, Ali S, Datta M. MiR135a targets IRS2 and regulates insulin signaling and glucose uptake in the diabetic gastrocnemius skeletal muscle. Biochim Biophys Acta. 2013;1832:1294-303.

3. Akhbari P, Richardson SJ, Morgan NG. Type 1 diabetes: interferons and the aftermath of pancreatic beta-cell enteroviral infection. Microorganisms. 2020;8:1419-37.

4. Albrechtsen A, Grarup N, Li Y, Spars $\varnothing$ T, Tian G, Cao H, Jiang T, Kim SY, Korneliussen T, Li Q, Nie C, Wu R, Skotte L, Morris AP, Ladenvall C, Cauchi S, Stančáková A, Andersen G, Astrup A, Banasik K, Bennett AJ, Bolund L, Charpentier G, Chen Y, Dekker JM, Doney AS, Dorkhan M, Forsen T, Frayling TM, Groves CJ, Gui Y, Hallmans G, Hattersley AT, He K, Hitman GA, Holmkvist J, Huang S, Jiang H, Jin X, Justesen JM, Kristiansen K, Kuusisto J, Lajer M, Lantieri O, Li W, Liang H, Liao Q, Liu X, Ma T, Ma X, Manijak MP, Marre M, Mokrosiński J, Morris AD, Mu B, Nielsen AA, Nijpels G, Nilsson P, Palmer CN, Rayner NW, Renström F, Ribel Madsen R, Robertson N, Rolandsson O, Rossing P, Schwartz TW D. E.S.I.R. Study Group, Slagboom PE, Sterner M; DIAGRAM Consortium, Tang M, Tarnow L, Tuomi T, van't Riet E, van Leeuwen N, Varga TV, Vestmar MA, Walker M, Wang B, Wang Y, Wu H, Xi F, Yengo L, Yu C, Zhang X, Zhang J, Zhang Q, Zhang W, Zheng H, Zhou Y, Altshuler D, 't Hart LM, Franks PW, Balkau B, Froguel P, McCarthy MI, Laakso M, Groop L, Christensen C, Brandslund I, Lauritzen T, Witte DR, Linneberg A, Jørgensen T, Hansen T, Wang J, Nielsen R, Pedersen O. Exome sequencing-driven discovery of coding polymorphisms associated with common metabolic phenotypes. Diabetologia. 2013;56:298-310.

5. Altshuler D, Hirschhorn JN, Klannemark M, Lindgren CM, Vohl MC, Nemesh J, Lane CR, Schaffner SF, Bolk S, Brewer C, Tuomi T, Gaudet D, Hudson TJ, Daly M, Groop L, Lander ES. The common PPARgamma Pro12Ala polymorphism is associated with decreased risk of type 2 diabetes. Nat Genet. 2000;26:76-80.

6. Assmann TS, Recamonde Mendoza M, Puñales M, Tschiedel B, Canani LH, Crispim D. MicroRNA expression profile in plasma from type 1 diabetic patients: case-control study and bioinformatic analysis. Diabetes Res ClinPract. 2018;141:35-46.

7. Bagge A, Clausen TR, Larsen S, Ladefoged M, Rosenstierne MW, Larsen L, Vang O, Nielsen JH, Dalgaard LT. MicroRNA$29 \mathrm{a}$ is up-regulated in $\beta$-cells by glucose and decreases glucosestimulated insulin secretion. Biochem Biophys Res Commun. 2012;426:266-72.

8. Banting FG, Best CH. The internal secretion of the pancreas. J Lab Clin Med. 1922;7:465-80.

9. Banting FG, Grant F, Best CH. 4. The internal secretion of the pancreas. University of Toronto Press; 2016. pp. 42-60.

10. Banting FG, Best CH, Collip JB, Campbell WR, Fletcher AA. Pancreatic extracts in the treatment of diabetes mellitus. Can Med Assoc J. 1922;12:141-6.

11. Barrett JC, Clayton DG, Concannon P, Akolkar B, Cooper JD, Erlich HA, Julier C, Morahan G, Nerup J, Nierras C, Plagnol V, Pociot F, Schuilenburg H, Smyth DJ, Stevens H, Todd JA, Walker NM, Rich SS. Genome-wide association study and meta-analysis find that over 40 loci affect risk of type 1 diabetes. Nat Genet. 2009;41:703-7.

12. Bell CG, Teschendorff AE, Rakyan VK, Maxwell AP, Beck S, Savage DA. Genome-wide DNA methylation analysis for diabetic 
nephropathy in type 1 diabetes mellitus. BMC Med Genet. 2010;3:33.

13. Belot MP, Fradin D, Mai N, Le Fur S, Zélénika D, Kerr Conte J, Pattou F, Lucas B, Bougnères P. CpG methylation changes within the IL2RA promoter in type 1 diabetes of childhood onset. PLoS ONE. 2013;8:e68093.

14. Bliss M. Resurrections in Toronto: the emergence of insulin. Horm Res Paediatr. 2005;64:98-102.

15. Cerna M. Epigenetic regulation in etiology of type 1 diabetes mellitus. Int J Mol Sci. 2019;21:36.

16. Chambers JC, Loh M, Lehne B, Drong A, Kriebel J, Motta V, Wahl S, Elliott HR, Rota F, Scott WR, Zhang W, Tan ST, Campanella G, Chadeau Hyam M, Yengo L, Richmond RC, Adamowicz Brice M, Afzal U, Bozaoglu K, Mok ZY, Kooner JS. Epigenome-wide association of DNA methylation markers in peripheral blood from Indian Asians and Europeans with incident type 2 diabetes: a nested case-control study. Lancet Diabetes Endocrinol. 2015;3:526-34.

17. Chen G, Bentley A, Adeyemo A, Shriner D, Zhou J, Doumatey A, Huang H, Ramos E, Erdos M, Gerry N, Herbert A, Christman M, Rotimi C. Genome-wide association study identifies novel loci association with fasting insulin and insulin resistance in African Americans. Hum Mol Genet. 2012;21:4530-6.

18. Chen SS, Jenkins AJ, Majewski H. Elevated plasma prostaglandins and acetylated histone in monocytes in Type 1 diabetes patients. Diabet Med. 2009;26:182-6.

19. Chien HY, Chen CY, Chiu YH, Lin YC, Li WC. Differential microRNA profiles predict diabetic nephropathy progression in Taiwan. Int J Med Sci. 2016;13:457-65.

20. Chowdhury S, Ghosh S, Das AK, Sil PC. Ferulic acid protects hyperglycemia-induced kidney damage by regulating oxidative insult, inflammation and autophagy. Front Pharmacol. 2019;10:27.

21. Chowdhury S, Ghosh S, Rashid K, Sil PC. Deciphering the role of ferulic acid against streptozotocin-induced cellular stress in the cardiac tissue of diabetic rats. Food Chem Toxicol. 2016;97:187-98.

22. Chuang JC, Jones PA. Epigenetics and microRNAs. Pediatr Res. 2007;61:24-9.

23. Concannon P, Onengut Gumuscu S, Todd JA, Smyth DJ, Pociot F, Bergholdt R, Akolkar B, Erlich HA, Hilner JE, Julier C, Morahan G, Nerup J, Nierras CR, Chen WM, Rich SS. A human type 1 diabetes susceptibility locus maps to chromosome 21q22.3. Diabetes. 2008;57:2858-61.

24. Cooper JD, Smyth DJ, Smiles AM, Plagnol V, Walker NM, Allen JE, Downes K, Barrett JC, Healy BC, Mychaleckyj JC, Warram JH, Todd JA. Meta-analysis of genome-wide association study data identifies additional type 1 diabetes risk loci. Nat Genet. 2008;40:1399-401.

25. Dale HH. III. On the "islets of Langerhans" in the pancreas. Philosophical Transactions of the Royal Society of London. Series B, Containing Papers of a Biological Character 197. 1905;225-238:25-46.

26. Damcott CM, Pollin TI, Reinhart LJ, Ott SH, Shen H, Silver KD, Mitchell BD, Shuldiner AR. Polymorphisms in the transcription factor 7-like 2 (TCF7L2) gene are associated with type 2 diabetes in the Amish: replication and evidence for a role in both insulin secretion and insulin resistance. Diabetes. 2006;55:2654-9.

27. Dayeh T, Tuomi T, Almgren P, Perfilyev A, Jansson PA, de Mello VD, Pihlajamäki J, Vaag A, Groop L, Nilsson E, Ling C. DNA methylation of loci within ABCG1 and PHOSPHO1 in blood DNA is associated with future type 2 diabetes risk. Epigenetics. 2016;11:482-8.

28. de Jong VM, Van Der Slik AR, Laban S, Van't Slot R, Koeleman BP, Zaldumbide A, Roep BO. Survival of autoreactive T lymphocytes by microRNA-mediated regulation of apoptosis through TRAIL and Fas in type 1 diabetes. Genes Immun. 2016;17:342-8.

29. Deeb SS, Fajas L, Nemoto M, Pihlajamäki J, Mykkänen L, Kuusisto J, Laakso M, Fujimoto W, Auwerx J. A Pro12Ala substitution in PPARgamma2 associated with decreased receptor activity, lower body mass index and improved insulin sensitivity. Nat Genet. 1998;20:284-7.

30. Delić D, Eisele C, Schmid R, Baum P, Wiech F, Gerl M, Zimdahl H, Pullen SS, Urquhart R. Urinary exosomal miRNA signature in type II diabetic nephropathy patients. PLoS ONE. 2016;11:1729-45.

31. Denis H, Ndlovu MN, Fuks F. Regulation of mammalian DNA methyltransferases: a route to new mechanisms. EMBO Rep. 2011;12:647-56.

32. Devendra D, Liu E, Eisenbarth GS. Type 1 diabetes: recent developments. BMJ. 2004;328:750-4.

33. Dewitt LM. Morphology and physiology of areas of Langerhans in some vertebrates. J Exp Med. 1906;8:193-239.

34. DIAMOND Project Group. Incidence and trends of childhood Type 1 diabetes worldwide 1990-1999. Diabetic Med. 2006;23:857-66.

35. Donath X, Saint-Martin C, Dubois-Laforgue D, Rajasingham R, Mifsud F, Ciangura C, Timsit J, Bellanné-Chantelot C. Next-generation sequencing identifies monogenic diabetes in $16 \%$ of patients with late adolescence/adult-onset diabetes selected on a clinical basis: a cross-sectional analysis. BMC Med. 2019;17:1-10.

36. Dorman JS, Steenkiste AR, O'Leary LA, McCarthy BJ, Lorenzen T, Foley TP. Type 1 diabetes in offspring of parents with type 1 diabetes: the tip of an autoimmune iceberg? Pediatr Diabetes. 2000;2001(1):17-22.

37. Dreon DM, Frey Hewitt B, Ellsworth N, Williams PT, Terry RB, Wood PD. Dietary fat: carbohydrate ratio and obesity in middle-aged men. Am J Clin Nutr. 1988;47:995-1000.

38. El Samahy MH, Adly AA, Elhenawy YI, Ismail EA, Pessar SA, Mowafy ME, Saad MS, Mohammed HH. Urinary miRNA-377 and miRNA-216a as biomarkers of nephropathy and subclinical atherosclerotic risk in pediatric patients with type 1 diabetes. J Diabetes Complic. 2018;32:185-92.

39. Escaño AK. Insulin, other hypoglycemic drugs, and glucagon. Side Eff Drugs Annu. 2015;37:521-37.

40. Fabian MR, Sonenberg N, Filipowicz W. Regulation of mRNA translation and stability by microRNAs. Annu Rev Biochem. 2010;79:351-79.

41. Feng J, Xing W, Xie L. Regulatory roles of MicroRNAs in diabetes. Int J Mol Sci. 2016;17:1729.

42. Filippi CM, Von Herrath MG. Viral trigger for type 1 diabetes: pros and cons. Diabetes. 2008;57:2863-71.

43. Flanagan SE, Haapaniemi E, Russell MA, Caswell R, Allen HL, De Franco E, McDonald TJ, Rajala H, Ramelius A, Barton J, Heiskanen K, HeiskanenKosma T, Kajosaari M, Murphy NP, Milenkovic T, Seppänen M, Lernmark Å, Mustjoki S, Otonkoski T, Kere J, Morgan NG, Ellard S, Hattersley AT. Activating germline mutations in STAT3 cause early-onset multi-organ autoimmune disease. Nat Genet. 2014;46:812-4.

44. Forouhi N, Merrick D, Goyder E, Ferguson B, Abbas J, Lachowycz K, Wild S. Diabetes prevalence in England, 2001-estimates from an epidemiological model. Diabetic Med. 2006;23:189-97.

45. Forouhi NG, Wareham NJ. Epidemiology of diabetes. Medicine (Abingdon, England: UK ed). 2014;42:698-702.

46. Forrest JM, Menser MA, Burgess JA. High frequency of diabetes mellitus in young adults with congenital rubella. Lancet. 1971;2:332-4.

47. Fradin D, Le Fur S, Mille C, Naoui N, Groves C, Zelenika D, McCarthy MI, Lathrop M, Bougnères P. Association of the CpG 
methylation pattern of the proximal insulin gene promoter with type 1 diabetes. PLoS ONE. 2012;7:e36278.

48. García Díaz DF, Pizarro C, Camacho Guillén P, Codner E, Soto N, Pérez BF. Expression of miR-155, miR-146a, and miR-326 in T1D patients from Chile: relationship with autoimmunity and inflammatory markers. Arch Endocrin Metab. 2018;62:34-40.

49. Georgiou DK. Phase transitions in insulin solutions and possible implications in living organisms. University of Houston; 2006.

50. Ghosh S, Chowdhury S, Das AK, Sil PC. Taurine ameliorates oxidative stress induced inflammation and ER stress mediated testicular damage in STZ-induced diabetic Wistar rats. Food Chem Toxicol. 2019;124:64-80.

51. Ghosh S, Chowdhury S, Sarkar P, Sil PC. Ameliorative role of ferulic acid against diabetes associated oxidative stress induced spleen damage. Food Chem Toxicol. 2018;118:272-86.

52. Gomes PR, Graciano MF, Pantaleão LC, Rennó AL, Rodrigues SC, Velloso LA, Latorraca MQ, Carpinelli AR, Anhê GF, Bordin S. Long-term disruption of maternal glucose homeostasis induced by prenatal glucocorticoid treatment correlates with miR-29 upregulation. Am J Physiol Endocrinol Metab. 2014;306:E109-20.

53. Gräff J, Tsai LH. Histone acetylation: molecular mnemonics on the chromatin. Nat Rev Neurosci. 2013;14:97-111.

54. Grarup N, Moltke I, Andersen MK, Dalby M, Vitting Seerup K, Kern T, Mahendran Y, Jørsboe E, Larsen CV, Dahl Petersen IK, Gilly A. Loss-of-function variants in ADCY3 increase risk of obesity and type 2 diabetes. Nat Gen. 2018;50:172-4.

55. Hameed S, Ellard S, Woodhead HJ, Neville KA, Walker JL, Craig ME, Armstrong T, Yu L, Eisenbarth GS, Hattersley AT. Persistently autoantibody negative (PAN) type 1 diabetes mellitus in children. Pediatr Diabetes. 2011;12:142-9.

56. Harris S. Banting's miracle: the story of the discoverer of insulin. Dent; 1946.

57. Hashimoto N, Tanaka T. Role of miRNAs in the pathogenesis and susceptibility of diabetes mellitus. J Hum Genet. 2017;62:141-50.

58. Hidalgo B, Irvin MR, Sha J, Zhi D, Aslibekyan S, Absher D, Tiwari HK, Kabagambe EK, Ordovas JM, Arnett DK. Epigenome-wide association study of fasting measures of glucose, insulin, and HOMA-IR in the Genetics of Lipid Lowering Drugs and Diet Network study. Diabetes. 2014;63:801-7.

59. Honeyman MC, Coulson BS, Stone NL, Gellert SA, Goldwater PN, Steele CE, Couper JJ, Tait BD, Colman PG, Harrison LC. Association between rotavirus infection and pancreatic islet autoimmunity in children at risk of developing type 1 diabetes. Diabetes. 2000;49:1319-24.

60. Hyöty H, Taylor KW. The role of viruses in human diabetes. Diabetologia. 2002;45:1353-61.

61. Ingelsson E, Langenberg C, Hivert MF, Prokopenko I, Lyssenko V, Dupuis J, Mägi R, Sharp S, Jackson AU, Assimes TL, Shrader P, Knowles JW, Zethelius B, AbbasiFA, Bergman RN, Bergmann A, Berne C, Boehnke M, Bonnycastle LL, Bornstein SR, Buchanan TA, Bumpstead SJ, Böttcher Y, Chines P, Collins FS, Cooper CC, Dennison EM, Erdos MR, Ferrannini E, Fox CS, Graessler J, Hao K, Isomaa B, Jameson KA, Kovacs P, Kuusisto J, Laakso M, Ladenvall C, Mohlke KL, Morken MA, Narisu N, Nathan DM, Pascoe L, Payne F, Petrie JR, Sayer AA, Schwarz PE, Scott LJ, Stringham HM, Stumvoll M, Swift AJ, Syvänen AC, Tuomi T, Tuomilehto J, Tönjes A, Valle TT, Williams GH, Lind L, Barroso I, Quertermous T, Walker M, Wareham NJ, Meigs JB, McCarthy MI, Groop L, Watanabe RM, Florez, JC. Detailed physiologic characterization reveals diverse mechanisms for novel genetic Loci regulating glucose and insulin metabolism in humans. Diabetes. 2010;59:1266-75.

62. Jiménez Chillarón JC, Díaz R, Martínez D, Pentinat T, Ramón Krauel M, Ribó S, Plösch T. The role of nutrition on epigenetic modifications and their implications on health. Biochimie. 2012;94:2242-63.

63. Jin W, Patti ME. Genetic determinants and molecular pathways in the pathogenesis of Type 2 diabetes. Clin Sci. 2009;116:99-111.

64. Karnieli E, Armoni M. Transcriptional regulation of the insulinresponsive glucose transporter GLUT4 gene: from physiology to pathology. Am J Physiol Endocrinol Metab. 2008;295:E38-45.

65. Kilpeläinen TO, Zillikens MC, Stančákova A, Finucane FM, Ried JS, Langenberg C, Zhang W, Beckmann JS, Luan J, Vandenput L, Styrkarsdottir U, Zhou Y, Smith AV, Zhao JH, Amin N, Vedantam S, Shin SY, Haritunians T, Fu M, Feitosa MF, Kumari M, Halldorsson BV, Tikkanen E, Mangino M, Hayward C, Song C, Arnold AM, Aulchenko YS, Oostra BA, Campbell H, Cupples LA, Davis KE, Döring A, Eiriksdottir G, Estrada K, Fernández Real JM, Garcia M, Gieger C, Glazer NL, Guiducci C, Hofman A, Humphries SE, Isomaa B, Jacobs LC, Jula A, Karasik D, Karlsson MK, Khaw KT, Kim LJ, Kivimäki M, Klopp N, Kühnel B, Kuusisto J, Liu Y, Ljunggren O, Lorentzon M, Luben RN, McKnight B, Mellström D, Mitchell BD, Mooser V, Moreno JM, Männistö S, O'Connell JR, Pascoe L, Peltonen L, Peral B, Perola M, Psaty BM, Salomaa V, Savage DB, Semple RK, SkaricJuric T, Sigurdsson G, Song KS, Spector TD, Syvänen AC, Talmud PJ, Thorleifsson G, Thorsteinsdottir U, Uitterlinden AG, Van Duijn CM, Vidal Puig A, Wild SH, Wright AF, Clegg DJ, Schadt E, Wilson JF, Rudan I, Ripatti S, Borecki IB, Shuldiner AR, Ingelsson E, Jansson JO, Kaplan RC, Gudnason V, Harris TB, Groop L, Kiel DP, Rivadeneira F, Walker M, Barroso I, Vollenweider P, Waeber G, Chambers JC, Kooner JS, Soranzo N, Hirschhorn JN, Stefansson K, Wichmann HE, Ohlsson C, O'Rahilly S, Wareham NJ, Speliotes EK, Fox CS, Laakso M, Loos RJ. Genetic variation near IRS1 associates with reduced adiposity and an impaired metabolic profile. Nat Genet. 2011;43:753-60.

66. Klose RJ, Bird AP. Genomic DNA methylation: the mark and its mediators. Trends Biochem Sci. 2006;31:89-97.

67. Knowles JW, Xie W, Zhang Z, Chennamsetty I, Assimes TL, Paananen J, Hansson O, Pankow J, Goodarzi MO, CarcamoOrive I, Morris AP, Chen YD, Mäkinen VP, Ganna A, Mahajan A, Guo X, Abbasi F, Greenawalt DM, Lum P, Molony C, Lind L, Lindgren C, Raffel LJ, Tsao PS, Schadt EE, Rotter JI, Sinaiko A, Reaven G, Yang X, Hsiung CA, Groop L, Cordell HJ, Laakso M, Hao K, Ingelsson E, Frayling TM, Weedon MN, Walker M, Quertermous T. Identification and validation of $\mathrm{N}$-acetyltransferase 2 as an insulin sensitivity gene. J Clin Invest. 2015;125:1739-51.

68. Kohil A, Al Asmakh M, Al Shafai M, Terranegra A. The interplay between diet and the epigenome in the pathogenesis of type-1 diabetes. Front Nutr. 2020;7:612115.

69. Kohli RM, Zhang Y. TET enzymes, TDG and the dynamics of DNA demethylation. Nature. 2013;502:472-9.

70. Kulkarni H, Kos MZ, Neary J, Dyer TD, Kent JW Jr, Göring $\mathrm{HH}$, Cole SA, Comuzzie AG, Almasy L, Mahaney MC, Curran JE, Blangero J, Carless MA. Novel epigenetic determinants of type 2 diabetes in Mexican-American families. Hum Mol Genet. 2015;24:5330-44.

71. Landstra CP, De Koning EJ. COVID-19 and diabetes: understanding the interrelationship and risks for a severe course. Front Endocrinol. 2021;12:599-616.

72. Langenberg C, Lotta LA. Genomic insights into the causes of type 2 diabetes. Lancet. 2018;391:2463-74.

73. Langerhans $\mathrm{P}$, Morrison H. Contributions to the microscopic anatomy of the pancreas. Bull Hist Med. 1937;5:259-97.

74. Li JY, Yong TY, Michael MZ, Gleadle JM. Review: the role of microRNAs in kidney disease. Nephrol. 2010;15:599-608.

75. Lim S, Bae JH, Kwon HS, Nauck MA. COVID-19 and diabetes mellitus: from pathophysiology to clinical management. Nat Rev Endocrinol. 2021;17:11-30. 
76. Lin X, Guan H, Huang Z, Liu J, Li H, Wei G, Cao X, Li Y. Downregulation of Bcl-2 expression by miR-34a mediates palmitate-induced Min6 cells apoptosis. J Diabetes Res. 2014;2014:1729-35.

77. Lintz W. Practical deductions from urinary findings in diabetes. JAMA. 1910;54:866-8.

78. Liu PH, Chang YC, Jiang YD, Chen WJ, Chang TJ, Kuo SS, Lee KC, Hsiao PC, Chiu KC, Chuang LM. Genetic variants of TCF7L2 are associated with insulin resistance and related metabolic phenotypes in Taiwanese adolescents and Caucasian young adults. J Clin Endocrinol Metab. 2009;94:3575-82.

79. Long J, Wang Y, Wang W, Chang BH, Danesh FR. MicroRNA$29 \mathrm{c}$ is a signature microRNA under high glucose conditions that targets Sprouty homolog 1, and its in vivo knockdown prevents progression of diabetic nephropathy. J Biol Chem. 2011;286:11837-48.

80. MacLeod JB, Frederick G. Banting: giving prospects for life from the past to the new millennium. Arch Surg. 2006;141:705-7.

81. Mannino GC, Andreozzi F, Sesti G. Pharmacogenetics of type 2 diabetes mellitus, the route toward tailored medicine. Diabetes Metab. 2019;35:e3109.

82. Menon S, Rajesh G, Balakrishnan V. Pancreas and diabetes mellitus: the relationship between the organ and the disease. J Assoc Phys India. 2015;63:51-8.

83. Menser MA, Forrest JM, Bransby RD. Rubella infection and diabetes mellitus. Lancet. 1978;1:57-60.

84. Miao F, Chen Z, Zhang L, Liu Z, Wu X, Yuan YC, Natarajan R. Profiles of epigenetic histone post-translational modifications at type 1 diabetes susceptible genes. J Biol Chem. 2012;287:16335-45.

85. Moltchanova E, Schreier N, Lammi N, Karvonen M. Seasonal variation of diagnosis of Type 1 diabetes mellitus in children worldwide. Diabetic Med. 2009;2009(26):673-8.

86. Moltke I, Grarup N, Jørgensen ME, Bjerregaard P, Treebak JT, Fumagalli M, Korneliussen TS, Andersen MA, Nielsen TS, Krarup NT, Gjesing AP, Zierath JR, Linneberg A, Wu X, Sun G, Jin X, Al Aama J, Wang J, Borch Johnsen K, Pedersen O, Nielsen R, Albrechtsen A, Hansen T. A common Greenlandic TBC1D4 variant confers muscle insulin resistance and type 2 diabetes. Nature. 2014;512:190-3.

87. Moreno H, Serrano AL, Santalucía T, Gumá A, Cantó, Brand NJ, Palacin M, Schiaffino S, Zorzano A. Differential regulation of the muscle-specific GLUT4 enhancer in regenerating and adult skeletal muscle. J Biol Chem 2003;278:40557-40564.

88. Mrena S, Virtanen SM, Laippala P, Kulmala P, Hannila ML, Akerblom HK, Knip M. Models for predicting type 1 diabetes in siblings of affected children. Diabetes Care. 2006;29:662-7.

89. Nasykhova YA, Barbitoff YA, Serebryakova EA, Katserov DS, Glotov AS. Recent advances and perspectives in next generation sequencing application to the genetic research of type 2 diabetes. World J Diabetes. 2019;10:376-95.

90. Ni W, Yang X, Yang D, Bao J, Li R, Xiao Y, Hou C, Wang H, Liu J, Yang D, Xu Y. Role of angiotensin-converting enzyme 2 (ACE2) in COVID-19. Crit Care. 2020;24:1-10.

91. Nogueira TC, Paula FM, Villate O, Colli ML, Moura RF, Cunha DA, Marselli L, Marchetti P, Cnop M, Julier C, Eizirik DL. GLIS3, a susceptibility gene for type 1 and type 2 diabetes, modulates pancreatic beta cell apoptosis via regulation of a splice variant of the BH3-only protein Bim. PLoS Gen. 2013;9:e1003532.

92. O'Neill LA, Sheedy FJ, McCoy CE. MicroRNAs: the finetuners of Toll-like receptor signalling. Nature Rev Immunol. 2011;11:163-75.

93. Onengut Gumuscu S, Ewens KG, Spielman RS, Concannon P. A functional polymorphism $(1858 \mathrm{C} / \mathrm{T})$ in the PTPN22 gene is linked and associated with type I diabetes in multiplex families. Genes Immun. 2004;5:678-80.

94. Ozanne SE, Jensen CB, Tingey KJ, Storgaard H, Madsbad S, Vaag AA. Low birthweight is associated with specific changes in muscle insulin-signalling protein expression. Diabetologia. 2005;48:547-52.

95. Pak CY, Eun HM, McArthur RG, Yoon JW. Association of cytomegalovirus infection with autoimmune type 1 diabetes. Lancet. 1988;2:1-4.

96. Park JH, Stoffers DA, Nicholls RD, Simmons RA. Development of type 2 diabetes following intrauterine growth retardation in rats is associated with progressive epigenetic silencing of Pdx1. J Clin Investig. 2008;118:2316-24.

97. Piganelli JD, Mamula MJ, James EA. The role of $\beta$ cell stress and neo-epitopes in the immunopathology of type 1 diabetes. Front Endocrinol. 2020;11:624590-600.

98. Poy MN, Hausser J, Trajkovski M, Braun M, Collins S, Rorsman P, Zavolan M, Stoffel M. MiR-375 maintains normal pancreatic $\alpha$ - and $\beta$-cell mass. Proc Natl Acad Sci. 2009;106:5813-8.

99. Prokopenko I, Poon W, Mägi R, Prasad BR, Salehi SA, Almgren P, Osmark P, Bouatia Naji N, Wierup N, Fall T, Stančáková A, Barker A, Lagou V, Osmond C, Xie W, Lahti J, Jackson AU, Cheng YC, Liu J, O'Connell JR, Blomstedt PA, Fadista J, Alkayyali S, Dayeh T, Ahlqvist E, Taneera J, Lecoeur C, Kumar A, Hansson O, Hansson K, Voight BF, Kang HM, Levy Marchal C, Vatin V, Palotie A, Syvänen AC, Mari A, Weedon MN, Loos RJ, Ong KK, Nilsson P, Isomaa B, Tuomi T, Wareham NJ, Stumvoll M, Widen E, Lakka TA, Langenberg C, Tönjes A, Rauramaa R, Kuusisto J, Frayling TM, Froguel P, Walker M, Eriksson JG, Ling C, Kovacs P, Ingelsson E, McCarthy MI, Shuldiner AR, Silver KD, Laakso M, Groop L, Lyssenko V. A central role for GRB10 in regulation of islet function in man. PLoS Gen. 2014;10:e1004235.

100. Pugliese A, Zeller M, Fernandez A Jr, Zalcberg LJ, Bartlett RJ, Ricordi C, Pietropaolo M, Eisenbarth GS, Bennett ST, Patel DD. The insulin gene is transcribed in the human thymus and transcription levels correlated with allelic variation at the INS VNTR-IDDM2 susceptibility locus for type 1 diabetes. Nat Genet. 1997;15:293-7.

101. Raychaudhuri N, Raychaudhuri S, Thamotharan M, Devaskar SU. Histone code modifications repress glucose transporter 4 expression in the intrauterine growth-restricted offspring. $\mathrm{J}$ Biol Chem. 2008;283:13611-26.

102. Redondo MJ, Steck AK, Pugliese A. Genetics of type 1 diabetes. Pediatr Diabetes. 2018;19:346-53.

103. Redondo MJ, Yu L, Hawa M, Mackenzie T, Pyke DA, Eisenbarth GS, Leslie RD. Heterogeneity of type I diabetes: analysis of monozygotic twins in Great Britain and the United States. Diabetologia. 2001;44:354-62.

104. Roach P. New insulin analogues and routes of delivery. Clin Pharmacokinet. 2008;47:595-610.

105. Rodriguez-Calvo T. Enterovirus infection and type 1 diabetes: unraveling the crime scene. Clin Exp Immunol. 2019;195:15-24.

106. Roe BA. Frederick Sanger (1918-2013). Genome Res. 2014;24:xi-xii.

107. Rose NR, Klose RJ. Understanding the relationship between DNA methylation and histone lysine methylation. Biochim Biophys Acta. 2014;1839:1362-72.

108. Rosenfeld L. Insulin: discovery and controversy. Clin Chem. 2002;48:2270-88.

109. Rui J, Deng S, Lebastchi J, Clark PL, Usmani Brown S, Herold KC. Methylation of insulin DNA in response to proinflammatory cytokines during the progression of autoimmune diabetes in NOD mice. Diabetologia. 2016;59:1021-9. 
110. Ryu HY, Zhao D, Li J, Su D, Hochstrasser M. Histone sumoylation promotes Set3 histone-deacetylase complex-mediated transcriptional regulation. Nucl Acids Res. 2002;48:12151-68.

111. Scott RA, Fall T, Pasko D, Barker A, Sharp SJ, Arriola L, Balkau B, Barricarte A, Barroso I, Boeing H, Clavel Chapelon F, Crowe FL, Dekker JM, Fagherazzi G, Ferrannini E, Forouhi NG, Franks PW, Gavrila D, Giedraitis V, Grioni S, Groop LC, Kaaks R, Key TJ, Kühn T, Lotta LA, Nilsson PM, Overvad K, Palli D, Panico S, Quirós JR, Rolandsson O, Roswall N, Sacerdote C, Sala N, Sánchez MJ, Schulze MB, Siddiq A, Slimani N, Sluijs I, Spijkerman AM, Tjonneland A, Tumino R, van der AD, Yaghootkar H, McCarthy MI, Semple RK, Riboli E, Walker M, Ingelsson E, Frayling TM, Savage DB, Langenberg C, Wareham NJ. Common genetic variants highlight the role of insulin resistance and body fat distribution in type 2 diabetes, independent of obesity. Diabetes. 2014;63:4378-87.

112. Shampo MA, Kyle RA. Stamp Vignette on Medical Science: John JR Macleod-Nobel Prize for Discovery of Insulin. Mayo Clin Proc. 2006;81:1006.

113 Singh R, Chandel S, Dey D, Ghosh A, Roy S, Ravichandiran $\mathrm{V}$, Ghosh D. Epigenetic modification and therapeutic targets of diabetes mellitus. Biosci Rep. 2020;40:BSR20202160.

114. Smyth DJ, Cooper JD, Bailey R, Field S, Burren O, Smink LJ, Guja C, Ionescu Tirgoviste C, Widmer B, Dunger DB, Savage DA, Walker NM, Clayton DG, Todd JA. A genome-wide association study of nonsynonymous SNPs identifies a type 1 diabetes locus in the interferon-induced helicase (IFIH1) region. Nat Genet. 2006;38:617-9.

115. Sommese L, Benincasa G, Lanza M, Sorriento A, Schiano C, Lucchese R, Alfano R, Nicoletti GF, Napoli C. Novel epigeneticsensitive clinical challenges both in type 1 and type 2 diabetes. $\mathrm{J}$ Diabetes Complic. 2018;32:1076-84.

116. Tan SY, Merchant J. Frederick Banting (1891-1941): Discoverer of insulin. Singap Med J. 2017;58:2-3.

117. Trajkovski M, Hausser J, Soutschek J, Bhat B, Akin A, Zavolan M, Heim MH, Stoffel M. MicroRNAs 103 and 107 regulate insulin sensitivity. Nature. 2011;474:649-53.

118. Vafiadis P, Bennett ST, Todd JA, Nadeau J, Grabs R, Goodyer CG, Wickramasinghe S, Colle E, Polychronakos C. Insulin expression in human thymus is modulated by INS VNTR alleles at the IDDM2 locus. Nat Genet. 1997;15:289-92.

119. Vajo Z, Fawcett J, Duckworth WC. Recombinant DNA technology in the treatment of diabetes: insulin analogs. Endocr Rev. 2001;22:706-17.

120. Vecchio I, Tornali C, Bragazzi NL, Martini M. The discovery of insulin: an important milestone in the history of medicine. Front Endocrinol (Lausanne). 2018;9:613.

121. Vella A, Cooper JD, Lowe CE, Walker N, Nutland S, Widmer B, Jones R, Ring SM, McArdle W, Pembrey ME, Strachan DP, Dunger DB, Twells RC, Clayton DG, Todd JA. Localization of a type 1 diabetes locus in the IL2RA/CD25 region by use of tag single-nucleotide polymorphisms. Am J Hum Genet. 2005;76:773-9.

122. Walford GA, Gustafsson S, Rybin $\mathrm{D}$, Stančáková $\mathrm{A}$, Chen $\mathrm{H}$, Liu CT, Hong J, Jensen RA, Rice K, Morris AP, Mägi R, Tönjes A, Prokopenko I, Kleber ME, Delgado G, Silbernagel G, Jackson AU, Appel EV, Grarup N, Lewis JP, Montasser ME, Landenvall C, Staiger H, Luan J, Frayling TM, Weedon MN, Xie W, Morcillo S, Martínez Larrad MT, Biggs ML, Chen YD, Corbaton Anchuelo A, Færch K, Gómez Zumaquero JM, Goodarzi MO, Kizer JR, Koistinen HA, Leong A, Lind L, Lindgren C, Machicao F, Manning AK, Martín Núñez GM, Rojo Martínez G, Rotter JI, Siscovick DS, Zmuda JM, Zhang Z, Serrano Rios M, Smith U, Soriguer F, Hansen T, Jørgensen TJ, Linnenberg A, Pedersen
O, Walker M, Langenberg C, Scott RA, Wareham NJ, Fritsche A, Häring HU, Stefan N, Groop L, O'Connell JR, Boehnke M, Bergman RN, Collins FS, Mohlke KL, Tuomilehto J, März W, Kovacs P, Stumvoll M, Psaty BM, Kuusisto J, Laakso M, Meigs JB, Dupuis J, Ingelsson E, Florez JC. Genome-Wide Association study of the modified stumvoll insulin sensitivity index identifies BCL2 and FAM19A2 as novel insulin sensitivity loci. Diabetes. 2016;65:3200-11.

123. Westman EC, Yancy WS, Humphreys M. Dietary treatment of diabetes mellitus in the pre-insulin era (1914-1922). Perspect Biol Med. 2006;49:77-83.

124. Whitford I, Quereshi S, Szulc AL. The discovery of insulin: is there glory enough for all? Einstein J Biol Med. 2016;28:12-7.

125. Williams M. Past masters: John James Rickard Macleod (18761935). Diabetologia. 2005;48:A7.

126. Willmer T, Johnson R, Louw J, Pheiffer C. Blood-based DNA methylation biomarkers for type 2 diabetes: potential for clinical applications. Front Endocrinol (Lausanne). 2018;9:744-60.

127. Zhou MS, Schulman IH, Zeng Q. Link between the renin-angiotensin system and insulin resistance: implications for cardiovascular disease. Vasc Med. 2012;17:330-41.

128. Yan S, Wang T, Huang S, Di Y, Huang Y, Liu X, Luo Z, Han W, An B. Differential expression of microRNAs in plasma of patients with prediabetes and newly diagnosed type 2 diabetes. Acta Diabetol. 2016;53:1-10.

129. Yang WM, Jeong HJ, Park SW, Lee W. Obesity-induced miR$15 \mathrm{~b}$ is linked causally to the development of insulin resistance through the repression of the insulin receptor in hepatocytes. Mol Nutr Food Res. 2015;59:2303-14.

130. Yang WM, Jeong HJ, Park SY, Lee W. Induction of miR-29a by saturated fatty acids impairs insulin signaling and glucose uptake through translational repression of IRS-1 in myocytes. FEBS Lett. 2014;588:2170-6.

131. Yang WM, Jeong HJ, Park SY, Lee W. Saturated fatty acidinduced miR-195 impairs insulin signaling and glycogen metabolism in HepG2 cells. FEBS Lett. 2014;588:3939-46.

132. Zhang T, Lv C, Li L, Chen S, Liu S, Wang C, Su B. Plasma miR-126 is a potential biomarker for early prediction of type 2 diabetes mellitus in susceptible individuals. BioMed Res Int. 2013;2013:761617-23.

133. Zhang W, Xie HY, Ding SM, Xing CY, Chen A, Lai MC, Zhou $\mathrm{L}$, Zheng SS. CADM1 regulates the G1/S transition and represses tumorigenicity through the Rb-E2F pathway in hepatocellular carcinoma. Hepatob Pancreat Dis Int. 2016;15:289-96.

134. Zhao LP, Alshiekh S, Zhao M, Carlsson A, Larsson HE, Forsander G, Ivarsson SA, Ludvigsson J, Kockum I, Marcus C, Persson $M$. Next-generation sequencing reveals that HLA-DRB3,DRB4, and-DRB5 may be associated with islet autoantibodies and risk for childhood type 1 diabetes. Diabetes. 2016;65:710-8.

135. Zhu Y, You W, Wang H, Li Y, Qiao N, Shi Y, Zhang C, Bleich D, Han X. MicroRNA-24/MODY gene regulatory pathway mediates pancreatic $\beta$-cell dysfunction. Diabetes. 2013;62:3194-206.

136. Zou Q, Qu K, Luo Y, Yin D, Ju Y, Tang H. Predicting diabetes mellitus with machine learning techniques. Front Genet. 2018;9:515-25.

137. Zullo A, Sommese L, Nicoletti G, Donatelli F, Mancini FP, Napoli C. Epigenetics and type 1 diabetes: mechanisms and translational applications. Transl Res. 2017;185:85-93.

Publisher's Note Springer Nature remains neutral with regard to jurisdictional claims in published maps and institutional affiliations. 